Szántó, Ildikó. "Kis, Pál. 2016. Csillaggal nem jó járni most. Kis Pál budapesti fényképész naplója 1944. októberdecember ('Better Not Walk around with the Star Now - the Budapest Diary of Pál Kis between October and December 1944'). Foreword by Pál Závada. Budapest: Magvető. 128 pp. Photos; Fenyves, Katalin and Marianne Szalay, eds. 2015. A holokauszt és a családom ('The Holocaust and My Family'). Budapest: Park Könykiadó. 492 pp. Photos.." Hungarian Cultural Studies. e-Journal of the American Hungarian Educators Association, Volume 10 (2017 DOI: 10.5195/ahea.2017.291

\title{
Kis, Pál. 2016. Csillaggal nem jó járni most. Kis Pál budapesti fényképész naplója 1944. október-december ('Better Not Walk around with the Star Now - the Budapest Diary of Pál Kis between October and December 1944'). Foreword by Pál Závada. Budapest: Magvető. 128 pp. Photos; Fenyves, Katalin and Marianne Szalay, eds. 2015. A holokauszt és a családom ('The Holocaust and My Family'). Budapest: Park Könykiadó. 492 pp. Photos.
}

\section{Reviewed by Ildikó Szántó", Independent Scholar}

Pál Kis's Csillaggal nem jó járni most ['Better Not Walk around with the Star Now'] is the diary of a man who did not survive the Holocaust of Hungarian Jews; and as such it stands in contrast to A holokauszt és a családom ['The Holocaust and My Family'], a collection of Holocaust micro-histories of first-, second- and third-generational families originally posted on the Facebook site of a group of such families. Both these documentary books delineate the tragic fate of Hungarian Jews in the final months of 1944. The foreword to the Diary of Pál Kis by Pál Závada, the well-known contemporary Hungarian novelist, transports the reader to the Budapest of October 1944 as Závada describes the close surroundings of Kis and appraises him as an outstanding photgrapher (9-17). The Diary of Kis traces the weeks between mid-October and early December 1944 in the author's life. Following the Arrow Cross putsch on October 16, Kis, then a renowned Budapest photographer, was conscripted into forced labor-service in the Hungarian army. In his diary he describes in detail the conditions of the service and the various places where men like himself, mostly over the age of fifty and some seriously ill, were ordered to dig trenches without any food or drink from three in the morning until evening. The brutality of the gendarmes made it almost impossible to escape: "...if someone ventured out for half a meter from the line, where we had to cover each other, the rifle butt, the boot-heel, the brutal fist found its way to push him back into the line..." ['...ha félméternyire kimerészkedett valaki a sorból, ahol egymást fedezni kellett, már dolgozott a puskatus, csizmasarok, a durva ököl, mely befelé a sorba taszitott...'] (61).

At one point Kis escapes from his unit, yearning to return to his home, but he realizes that this would be far too dangerous as his house is one of the two thousand "Yellow-Star Houses," in

szanto.ildiko3@upcmail.hu

(cc) $\mathrm{Br}$

ULLS D-Serle
New articles in this journal are licensed under a Creative Commons Attribution 4.0 International License.

This journal is published by the University Library System of the University of Pittsburgh as part of its D-Scribe Digital Publishing Program and is cosponsored by the University of Pittsburgh Press 
Szántó, Ildikó. "Kis, Pál. 2016. Csillaggal nem jó járni most. Kis Pál budapesti fényképész naplója 1944. októberdecember ('Better Not Walk around with the Star Now - the Budapest Diary of Pál Kis between October and December 1944'). Foreword by Pál Závada. Budapest: Magvető. 128 pp. Photos; Fenyves, Katalin and Marianne Szalay, eds. 2015. A holokauszt és a családom ('The Holocaust and My Family'). Budapest: Park Könykiadó. 492 pp. Photos.." Hungarian Cultural Studies. e-Journal of the American Hungarian Educators Association, Volume 10 (2017 DOI: 10.5195/ahea.2017.291

which Jews have been forced to live since June 17 of the same year (Braham, The Politics of Genocide: The Holocaust in Hungary; New York: Columbia UP, 1981, vol. II, 1212). Therefore, all he can do is describe how, while riding by his house in a tram (itself a dangerous activity, given his situation), he dares only to look at the plaque with his name on the house door, hardly believing that he and the man carrying this name are really one and the same:

...I was watching my signboard from the tram, the thin, elegant letters with a low profile: "photographer, Pál Kis"... and the tram was taking me, ragged, sick, shattered... One cannot suppose even with the best intention, that this man is Pál Kis, who received the most prestigious award in 1925, the first master craftsman in Hungary who received several gold medals and awards from abroad...

[...És a villamosról néztem a cégtáblámat, a vékony betüs, elegáns, minden feltünést kerülö feliratot: "fotó Kis Pál"... és vitt a villamos toprongyosan, betegen, lelkileg összetörve...A legjobb akarattal sem lehetne rólam feltételezni: ez az a Kis Pál, aki Magyarországon 1925-ben a legnagyobb díjat nyerte, ö volt az ország elsö koszorús mestere - és több aranyérmet, diplomat, külföldí díjakat...] (64).

In a November 1944 long entry, Kis writes: "Looting and man hunts began again, identity checks on the street, better not walk around with the star now, people are carried off without any reason..." ['A rablás, embervadászat újból kezdödött, az utcán igazoltatnak, csillaggal nem jó járni most, az embert minden ok nélkül elhurcolják...'] (68). Kis and his family acquire false papers and during November 1944 they keep on moving, each separately, from one place to another, until on December 8 Kis is caught by the Arrow Cross gendarmes and transported to Buchenwald concentration camp. Since his diary was left behind in Budapest, all that we know about what happened to him after he left Budapest comes from the research of Alexandra Schmal, which was added to the diary at the time of its publication (17-41). Following an eighteen-day journey in a closed freight train, on December 25 the Hungarian transport of which Kis was part arrived at Buchenwald and a week later he was transferred to one of Buchenwald's satellite camps, the infamous Berga am Elster, where the average "life-span" was three weeks (30-31). Pál Kis perished on January 24, 1945, and his wife Ilona Klein did not survive either. Kis's diary was found after the war by his daughter, Shoshanna Shofrony, at his last hiding place in the photo studio of his brother, Sándor Kis (45). In 1992 Shofrony donated her father's diary, his drawings and other family documents to the Israeli Safed Museum of Hungarian Speaking Jewry. At the same time she also sent a typed copy of the diary and the drawings to the Budapest Jewish Museum and Archives (26, 45-46).

Katalin Fenyves and Marianne Szalay's co-edited A holokauszt és a családom ['The Holocaust and My Family'] consists of the printed records of a Facebook group by this name, originally launched by former Hungarian politician Mátyás Eörsi, which was intensively active throughout the year 2014 and is still, though much less, active at present. (https://www.facebook.com/groups/holokauszt.csaladom/?hc_ref=SEARCH). In the printed version, the editors include approximately one hundred and sixty family stories and more than one hundred photographs, thus transforming the potentially transient nature of the Facebook 
Szántó, Ildikó. "Kis, Pál. 2016. Csillaggal nem jó járni most. Kis Pál budapesti fényképész naplója 1944. októberdecember ('Better Not Walk around with the Star Now - the Budapest Diary of Pál Kis between October and December 1944'). Foreword by Pál Závada. Budapest: Magvető. 128 pp. Photos; Fenyves, Katalin and Marianne Szalay, eds. 2015. A holokauszt és a családom ('The Holocaust and My Family'). Budapest: Park Könykiadó. 492 pp. Photos.." Hungarian Cultural Studies. e-Journal of the American Hungarian Educators Association, Volume 10 (2017 DOI: 10.5195/ahea.2017.291

group and its postings into a definitive printed work available to all Hungarian-reading audiences and opening a dialogue between Hungarian Jews and non-Jewish Hungarians (9). This project is part of a whole stream of recent publications of 1944-45 documentary materials commemorating the Holocaust of Hungarian Jews (on which, in this journal, see Louise O. Vasvari's article in vol. 7 (2014) at: http://ahea.pitt.edu DOI: 10.5195/ahea.2014.139).

The entries in The Holocaust and My Family, culled from more than 6,300 Facebook posts, are divided into these entries: Holocaust survivors, second- and third-generation Holocaust survivors, provincial Jews and Jews in Pest, Jewish women, Jews living in mixed marriages in 1944, and non-Jewish rescuers. All of the non-Jewish material, including posts by Roma people and twenty stories of rescuers, made its way into the book, but of the much larger number of posts written by Jews only a chosen part appears in print. The editors' selection of the accounts by Jews derives from their preference of close family histories that were never published elsewhere and from their wish to publically memorialize individual tragedies and thus offer Hungarian readers a deeper understanding of the 1944 events in their country (https://moly.hu/konyvek/kaszt-adam-szerk-a-holokauszt-es-acsaladomhttps://moly.hu/konyvek/kaszt-adam-szerk-a-holokauszt-es-a-csaladom). In most cases these accounts come from first-generation Holocaust survivors who in 1944-45 were in their early teens or even younger. Their stories often sound familiar, close to similar ones that many of us have heard or read countless times, and yet each story is unique in that each survivor adds to it his or her specific nuances and stresses. Sonja Takács was saved by Swiss diplomat Carl Lutz in the last minute but even months after liberation her ordeal was far from over:

As a twelve and a half year old I sincerely believed that I would get my parents back. Everyone reassured me that they would return, for sure they'll return, but it's a long way...In August, when I turned thirteen, I gave up all hope. I took all the pills I found amongst the ruins of the flat. Only my parents' wonderful friends saw what was happening to me...

[Én 12 és fél évesen őszintén hittem abban,hogy visszakapom a szüleimet...Körülöttem mindeki azzal biztatott,hogy jönnek, biztosan jönnek, de hosszú az út.... Augusztusban, mikor 13 éves lettem,már nem hitegethettem magam tovább. Születésnapomon elövettem a lakás romjai között talált gyógyszert. Csak szüleim egy nagyszerü barátnöje vette észre, hogy mi történik velem...] (102-107).

For those of the second generation the loss of the large families they had before World War II and the absence of grandparents is a common experience. As for the third generation, they often relate the stories they heard from their survivor relatives, wishing to ensure that the survival legacy of their loved ones will be remembered. For example, the following brief exerpt from Judit Békefi's account, as she heard it from her grandmother, is one of the more detailed family stories in the book: Erzsi, Judit's grandmother, was called into forced labor service and transported to Györ, but after two months she managed to escape. She arrived at Déli Railway Station just when the Russians started to bomb the area. In the midst of the turmoil, she crossed the Chain Bridge and saw her aunt as she was taken to the Danube to be shot. Erzsi kept walking 
Szántó, Ildikó. "Kis, Pál. 2016. Csillaggal nem jó járni most. Kis Pál budapesti fényképész naplója 1944. októberdecember ('Better Not Walk around with the Star Now - the Budapest Diary of Pál Kis between October and December 1944'). Foreword by Pál Závada. Budapest: Magvető. 128 pp. Photos; Fenyves, Katalin and Marianne Szalay, eds. 2015. A holokauszt és a családom ('The Holocaust and My Family'). Budapest: Park Könykiadó. 492 pp. Photos.." Hungarian Cultural Studies. e-Journal of the American Hungarian Educators Association, Volume 10 (2017 DOI: 10.5195/ahea.2017.291

toward the ghetto and luckily she found her grandmother. Erzsi's granddaughter Judit describes this lucky reunion as well as her own sense of commitment to retell it all in these words:

Somehow she got back and found my great-great grandmother, weakened but still alive, in the Red Cross house, where they got through the remaining time. My grandmother told me this time and again, maybe she wanted me to pass on her story and I want to do this by all means.

[Valahogy visszakeveredett, és megtalálta az én dédnagymámat: legyengülve a vöröskeresztes házban, de élt. S itt vészelték át a hátralévö időt. Nagymamám ezt többször elmesélte, talán azt akarta, hogy továbbvigyem a történetet, és igyekszem is ezt megtenni minden eszközömmel] (193-197).

The posts of many both second- and third-generation Holocaust survivors reveal that while growing up in postwar and communist Hungary they knew nothing about the war or, in many cases, even about their Jewish roots, nor indeed about members of their families having been victims of the Holocaust. In many families the denial, the silence about the past, the survival guilt, the communist ideology or the continued assimilation were part of the selfsuppression concerning the past, which prevailed for decades after the Holocaust. The burial of the past was often justified by the wish of the parents to protect their children from their own anguish. Such is the case of Mária Katona, a granddaughter in a family of mixed marriage, who after learning about her best friend's tragic family history in a casual conversation returns home, fires her questions at her parents and then discovers that her paternal grandmother is Jewish:

- Why have you never talked about it? I aimed the question, having heaped on them Judith's frightful account.

- How could it have happened? Why did you allow it to!

I found out that several Jews were hidden by the family, but many good friends never returned.

- Why did you all remain silent! I didn't even know that there are Jews in this country!

- We don't make differences. We wanted you to not make any either. This is not a topic of discussion in our house, said my mother quietly.

[- Miért nem beszéltetek erröl soha? Szegezem nekik a kérdést, miutám rájuk zúdítottam Jutka isszonyatos beszámolóját.

- Hogy történhetett meg! Hogy hagytátok!'Megtudom, hogy a családban többen is bújtattak zsidókat, de sok jó barát nem tért vissza soha többé.

- Miért hallgattatok! Azt se tudtam, hogy az országban vannak zsidók is!

- Mi nem teszünk különbséget.Azt akartuk, ti se tegyetek. Ez nálunk nem téma! - mondta anyám halkan] (189-191).

The first-hand accounts of Holocaust survivors as they were passed on to the second and third generations offer the reader a view into the atrocities that these survivors lived through and how their traumas have been transmitted, whether directly or indirectly, to their third generation. 
Szántó, Ildikó. "Kis, Pál. 2016. Csillaggal nem jó járni most. Kis Pál budapesti fényképész naplója 1944. októberdecember ('Better Not Walk around with the Star Now - the Budapest Diary of Pál Kis between October and December 1944'). Foreword by Pál Závada. Budapest: Magvető. 128 pp. Photos; Fenyves, Katalin and Marianne Szalay, eds. 2015. A holokauszt és a családom ('The Holocaust and My Family'). Budapest: Park Könykiadó. 492 pp. Photos.." Hungarian Cultural Studies. e-Journal of the American Hungarian Educators Association, Volume 10 (2017 DOI: 10.5195/ahea.2017.291

Such are the stories, among many others, of women whose sexual organs were searched for hidden valuables or of survivors recalling the harsh threats of the Hungarian gendarmes herding them for deportation. The reader learns of the solidarity and sisterhood that helped women to get through a day in the camps or in the overcrowded "Yellow-Star Houses" in Budapest $(309,317)$. The final chapter of the book is devoted to the rescuers. With the exceptions of Sara Luca Karig (433) and László Ocskay (434), many of these ordinary people remained unknown, and even decades after the events all they can say is that they acted as human beings should towards other human beings. In addition to the texts, the family photographs reintegrate the lost loved ones into the personal accounts of their surviving relatives.

The tragedy of Hungarian Jewry lies in the fact that despite their ready assimilation into nineteenth-century Hungarian society, and in spite of the Emancipation granted them in 1867, during the following decades and well into the twentieth century antisemitic tendencies strengthened. In World War II Hungary became an ally of Nazi Germany and thus shared its murderous Final Solution for all European Jews. In a mere fifty-six days during the summer of 1944, 437,402 Hungarian Jews were deported and the majority of them were murdered (Braham, The Politics of Genocide: The Holocaust in Hungary, vol. II, 676). The failure of Jewish assimilation into Hungarian society is well summed up by Gyula Eörsi (1922-1992), the famous professor of law, who, close to the end of his life, reveals to his son, sobbing: "Zsidó vagyok" ['I'm Jewish'] (112). In other words, he identifies the central tenet of the interwar ChristianHungarian national ideology, by which Hungarians and Jews were regarded as separate peoples, and where "Jews had no place," but also the silence under postwar Communism about the Holocaust (Paul A. Hanebrink, In Defense of Christian Hungary - Religion, Nationalism, and Antisemitism, 1890-1944; Ithaca, N.Y.: Cornell UP, 2006, 231).

On June 21, 2014, as part of the seventieth anniversary of the Holocaust in Hungary, a memorial ceremony was held in the courtyard of the Budapest building where the studio of Pál Kis once stood and which in 1944-45 was, as said, one of the capital city's "Yellow-Star Houses." In the nearby Robert Capa Contemporary Photography Center, photo-historian Károly Kincses delivered a lecture on Pál Kis, while other memorial events were concurrently held in the capital's still existing seventy-six "Yellow-Star houses," in which visitors could see how the persecuted Jews lived before tens of thousands of them were sent to their death. Together, the two books surveyed in this review offer valuable insights into the fate of Hungarian Jews between 1944 and 1945 for students, Holocaust survivors and future generations. 